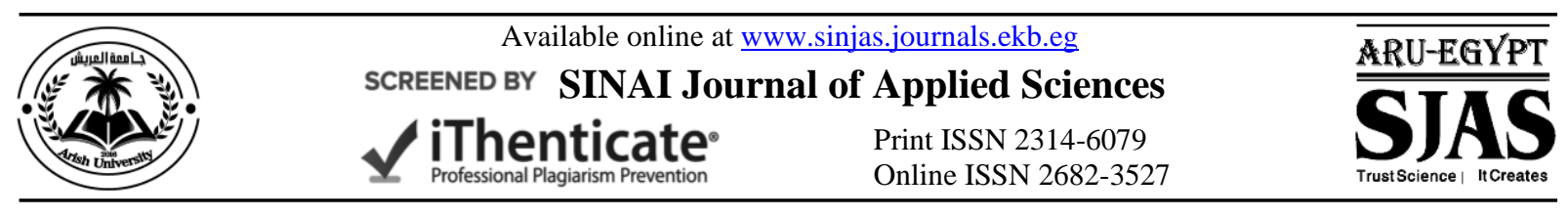

\title{
IDENTIFICATION AND TAXONOMIC STUDY OF SHRIMPS IN BARDAWIL LAGOON, NORTH SINAI, EGYPT
}

\author{
Samar A. Amin ${ }^{1}$, G.D.I. Hassanen ${ }^{2}$ and M.S. Ahmed ${ }^{3}$ \\ 1. Post-Grad. Stud., Dept. Fish Res., Fac. Environ. Agric. Sci., Arish Univ., Egypt. \\ 2. Dept. Fish Res., Fac. Environ. Agric. Sci., Arish Univ., Egypt. \\ 3. Fac. Aquacul. and Marine Fisheries, Arish Univ., Egypt.
}

\begin{tabular}{|c|c|}
\hline ARTICLE INFO & ABSTRACT \\
\hline Article history: & Taxonomic study of shrimp on the Bardawil lagoon, were studied in \\
\hline Received: $14 / 03 / 2021$ & specimens of shrimp collected from Bardawil lagoon fishers from Seasonal \\
\hline Revised: 19/03/2021 & occurrence of shrimp During, 2019. Identification of species was based on the \\
\hline Accepted: 01/04/2021 & morphological characters of rostrum (dorsal and ventral teeth), remarks of \\
\hline Available online: $13 / 04 / 2021$ & carapace, antenna, sub apical spines on telson and the colored pattern of the \\
\hline Keywords: & whole body based on standard keys and diagnoses available from the current \\
\hline Species, & literature. Modified Key identify shrimp species from Bardawil lagoon, was \\
\hline Shrimps, & prepared after morphometric analysis. A total of 5 species from belong to \\
\hline Taxonomic, & three genus; Penaeus, Melicertus and Metapenaeus. Among these, two \\
\hline Bardawil lagoon & species belong to the genus Penaeus (Penaeus semisulcatus (De Haan, 1844) \\
\hline & $\begin{array}{l}\text { and Penaeus (Marsupenaeus) japonicas (Bate, 1888). The species which } \\
\text { taken from genus Metapenaeus namely Metapenaeus stebbingi (Nobili, 1904) }\end{array}$ \\
\hline ( ) & $\begin{array}{l}\text { and Metapenaeus monoceros. (Fabricus, 1798), One species belong to the } \\
\text { genus Melicertus kerathurus. (Forskål, 1775). Additional research is needed }\end{array}$ \\
\hline $\begin{array}{l}\text { Check for } \\
\text { updates }\end{array}$ & to more clearly define the distribution of shrimp species in Bardawil lagoon. \\
\hline
\end{tabular}

\section{INTRODUCTION}

Penaeid shrimps are important resources for worldwide fisheries and aquaculture. They supply the increasing population with animal proteins and provide significant earnings of foreign exchange for developing countries (Jayawickrama, 2010). Without taxonomy, nobody would be sure of the identity of organisms whether they belonged to the same or different species as the failure to recognize fishes as distinct biological units can lead to wrong diagnosis (GuerraGarcia Without taxonomy, nobody would be sure of the identity of organisms whether they belonged to the same or different species as the failure to recognize fishes as distinct biological units can lead to wrong diagnosis (Guerra-Garcia et al., 2008; Keat-Chuan et al., 2017). This research is preliminary attempt to provide a detailed identification of shrimps in Bardawil lagoon.

\section{MATERIALS AND METHODS}

Bardawil lagoon (Fig. 1) is a shallow lagoon of high salinity. It's area about 685 $\mathrm{km}^{2}(165,000$ acres$)$ and extends for a distance of about $95 \mathrm{~km}$, from point $45 \mathrm{~km}$ east of Port Said to the point $18 \mathrm{~km}$ west of AlArish and its maximum width is $22 \mathrm{~km}$ and the average depth is $135 \mathrm{~cm}$ (Gafrd, 2009).

\section{Sampling and Morphological Identification}

The study was carried out during the 3 seasons (Summer- Spring-Autumn). The collection of 731 random samples of shrimp species from the commercial catch of Bardawil Lagoon, 2019. Which were iced in an ice bin and transported to the laboratory of the Institute of Environmental Studies, Arish University for taxonomic examinations and measurements. The present study was mainly based on the phenotype and meristic character observation of fresh specimens in the samples.

\footnotetext{
* Corresponding author: E-mail address: aminsamar8@gmail.com 


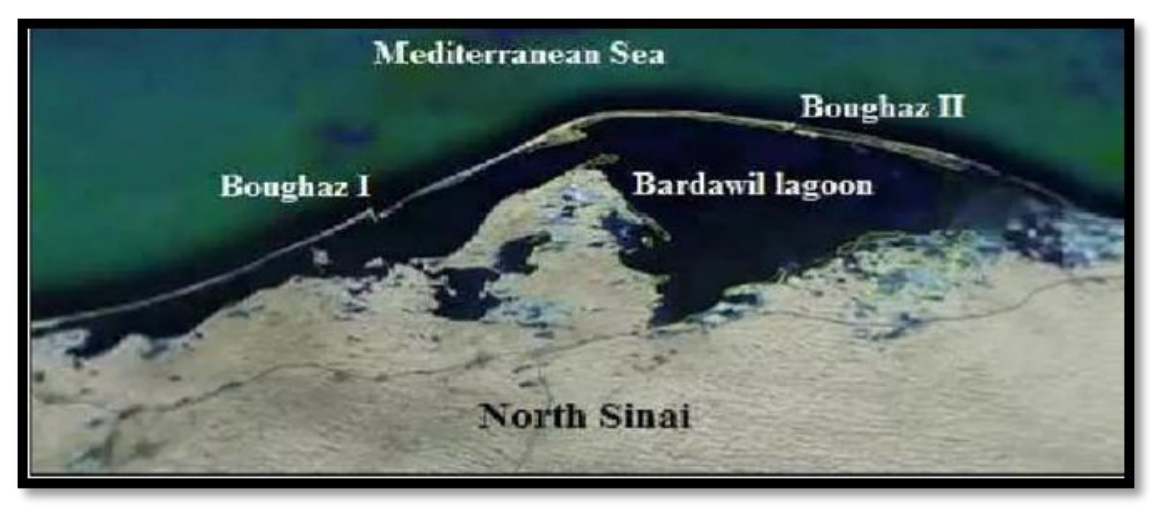

Fig. 1. Satellite image of Bardawil lagoon

The present study was mainly based on the phenotype and meristic character observation of fresh specimens in the samples. Shrimps were examined using hand lenses and under a binocular stereo microscope (OPTIKA Stereomicroscope MB5-4083.B5, Italy). Samples were determined at the species level and before Measurement, samples were separated on the basis of phenotype. The identity was confirmed with the help of widely used references (De Bruin et al., 1994; Carpenter and Niem, 1998 and Piratheepa et al., 2016).

\section{RESULTS AND DISCUSSION}

\section{Morphological Analyses and Shrimp Species}

In this study, a total of five species of Penaeid shrimps were identified by morphologically. Shrimp were determined based on the following morphological characteristics. Number of rostral teeth, down area telson and exopods on fifth pereiopods were considered one of the major morphological characteristics used to identify shrimp species, which is categorized under one family, the Penaeidae family. It became clear through the study, there are five species belong to three genus; Penaeus, Melicertus and Metapenaeus. Among these, two species belong to the genus Penaeus (Penaeus semisulcatus and Penaeus (Marsupenaeus) japonicas). The species which taken from genus Metapenaeus namely Metapenaeus stebbingi and Metapenaeus monoceros. One species belong to the genus Melicertus (Melicertus kerathurus). Morphometric characteristics showed more distinguish between individuals of Penaeus and Metapenaeus as the identification of shrimps traditionally are relied on morphometric analysis; however, it is well known that such characteristics are influenced by environmental conditions (Bowman et al., 1982). Piratheepa et al. (2016), described Penaeus semisulcatus as having a reddish brown to pale brown body color may be Dark in color. The pulpit has 5-8 teeth on the top and 2-4 teeth on the ventral side. Based on the morphological characteristics, two groups of $P$. semisulcatus are distinguished in the Persian Gulf. The first group is characterized by a reddish body color with deep red or brown transverse bands, cream and brown striped color of the whip antenna. Second group subspecies of $P$. persicus, is characterized by a creamy pink body color without distinct transverse stripes, and its whip antenna has a cream color without stripes (Rahnama $\boldsymbol{e t}$ al., 2010). Otero et al. (2013), were identified Marsupenaeus japonicus, result showed a well-developed rostrum with 7 - 11 teeth on the dorsal margin and 1 tooth on the ventral marginal. The body was pale, with brown bands and the pereiopods and pleopods were pale yellow near their bases with blue markings near the tips. FAO (2011) describe 
Melicertus kerathurus body is light creamy brown with gray spots and rust colored. Carapace is Creamy. Rostrum has Mostly 9 teeth on the top and 1 tooth appear on the ventral side. There are 3 cicatrices on the last abdominal segments. Piratheepa et al. (2016) descriptive remarks for Metapenaeus monoceros as follows body pink, antennae with a red Colour; pereopods and pleopods of same Colour as body, sometimes more intensely pink. Carapace is pink with a grayish dark spot. Rostrum has 9-12 teeth on the top and no tooth appear on the ventral side. The outer tip of the Telson is blue. Jayawickrama (2010). Describe of Metapenaeus stebbingi. Body white to creamy-yellow with grey and rust coloured specks; antennae Colour to grey-purplish. The rostrum there is no tooth on ventral side and 7-10 teeth on the top. Telson with spines. All of these results are in complete agreement with the results of this thesis in describing their type in terms of appearance.

\section{Key Identifies Shrimp Species from Bardawil Lagoon}

1. Rostrum with teeth on its dorsal side only . Genus Metapenaeus.

2. Rostrum with 9-12 teeth on dorsal side, telson with movable spines and there are basial spines on first 3 pereiopods ........ Metapenaeus monoceros.

3. Rostrum with $8-10$ teeth on dorsal side and no ischial spine on 1stpereiopod ........ Metapenaeus stebbingi.

4. Rostrum with teeth on its dorsal and ventral side.........Genus Penaeus.

5. Rostrum with 2-4 teeth on ventral side ......... Penaeus semisulcatus.

6. Rostrum with 5-8 teeth on dorsal side, and no spines on telson and antennae banded white and brown. Dark green to dark brown cross bands on the abdomen, leg with yellow and reddish bands ....... Penaeus semisulcatus.
7. Rostrum with one tooth on ventral side .... Penaeus (Marsupenaeus) japonicas and Melicertus kerathurus.

8. Rostrum with 9-10 teeth on dorsal side, pereiopods and pleopods yellow and blue and 3 pairs of movable spines on telson. Body with yellow and brown bands ......Penaeus (Marsupenaeus) japonicas.

9. Rostrum with 8-13 teeth on dorsal side and there are spines on base of first 2 pairs of pereiopods .......... Melicertus kerathurus.

Shrimps were identified based on the morphological characteristics. Through virtual examination and microscopic examination inside the laboratory, each species was determined separately by studying its phenotype as a follow:

\section{Penaeus semisulcatus (De Haan, 1844)}

\section{Common name}

Green tiger prawn.

\section{Colour}

Pale reddish brown with dark brown dorsal transverse stripes. White and brown antenna.

\section{Descriptive remarks}

The carapace is reddish brown Colour with Brown transverse lines. The rostrum has 5-8 teeth on the top and 2-4teeth appear on the ventral side. Antenna banded white and brown.

\section{Penaeus (Marsupenaeus) japonicus (Spence Bate, 1888)}

\section{Common name}

Kuruma prawn

\section{Colour}

Lightly brown to greenish brown with blue edge at tail fan.

\section{Descriptive remarks}

The carapace is soft and shiny. The rostrum has one tooth on ventral side and 9 teeth on the top. Telson has a mixture of three colors brown, yellow and blue. 

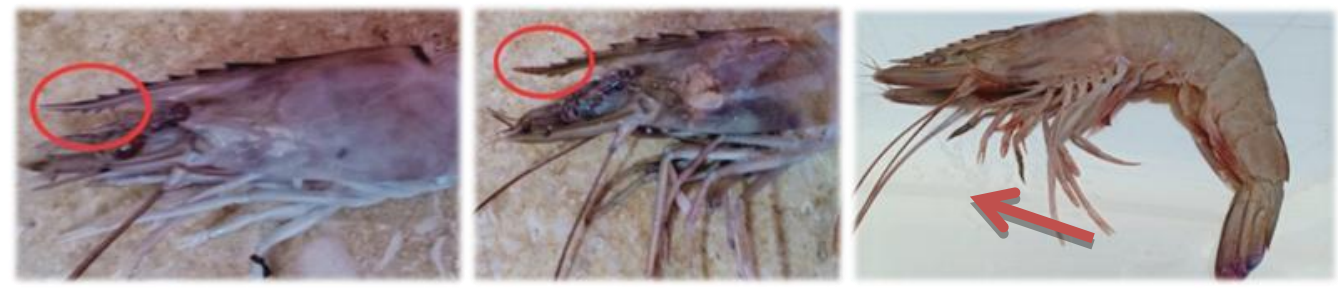

Fig. 2. Penaeus semisulcatus from Bardawil lagoon during fishing season, 2019
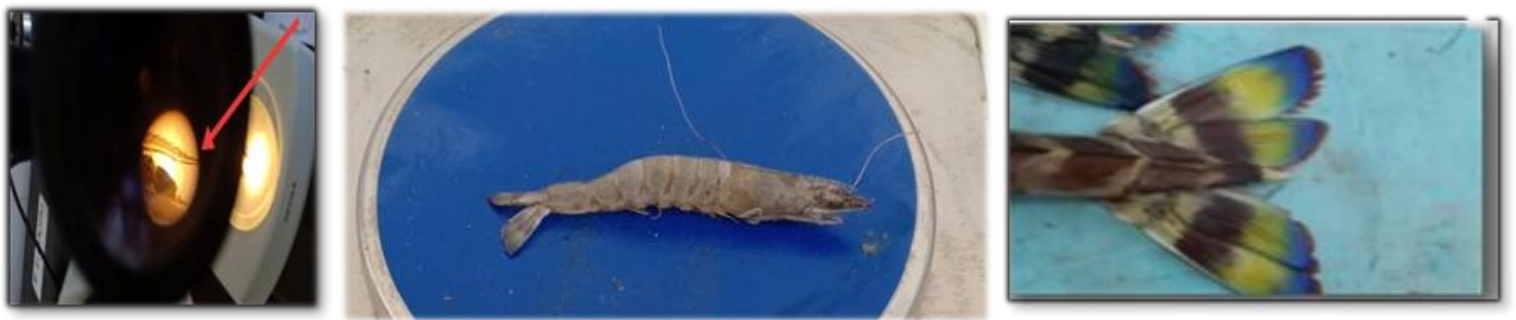

Fig. 3. Penaeus (Marsupenaeus) japonicus from Bardawil lagoon during fishing season, 2019
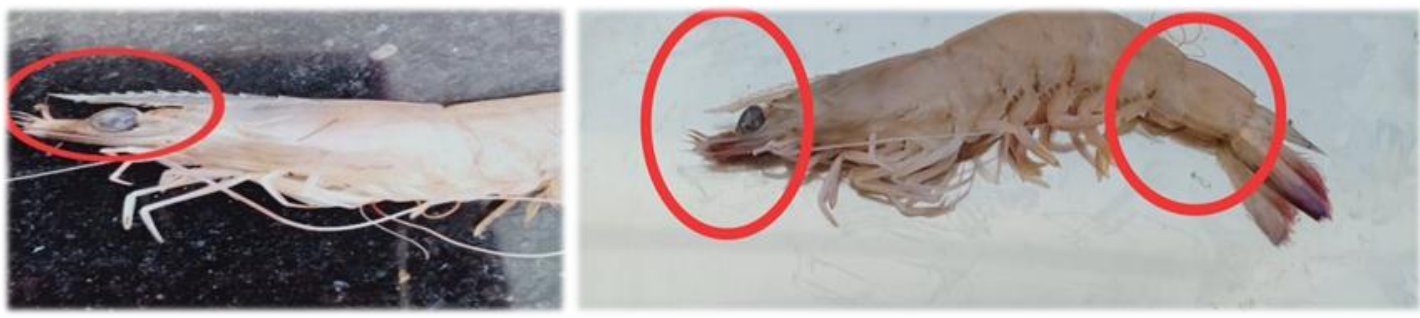

Fig. 4. Melicertus kerathurus from Bardawil lagoon during fishing season, 2019

\section{Melicertus kerathurus (Forskål, 1775) \\ Colour}

The body is light creamy brown with gray spots and rust colored.

\section{Descriptive remarks}

The carapace is Creamy. The rostrum has 9 teeth on the top and 1 tooth appear on the ventral side. There are 3 cicatrices on the last abdominal segments.

Metapenaeus monoceros (Fabricus, 1798)

\section{Common name}

Ginger prawn.

\section{Colour}

Body pink, antennae with a red Colour; pereopods and pleopods of same Colour as body, sometimes more intensely pink.

\section{Descriptive remarks}

The carapace is pink with a grayish dark spot. The rostrum has 9-12 teeth on the top and no tooth appear on the ventral side. The outer tip of the Telson is blue.

\section{Metapenaeus stebbingi (Nobili, 1904)}

\section{Common name}

Peregrine shrimp

\section{Colour}

White to creamy-yellow with grey coloured specks and antennae by Colour grey.

\section{Descriptive remarks}

The carapace is cream colour. The rostrum has 7-10 teeth on the top and no teeth appear on the ventral side. Telson with a spine. 

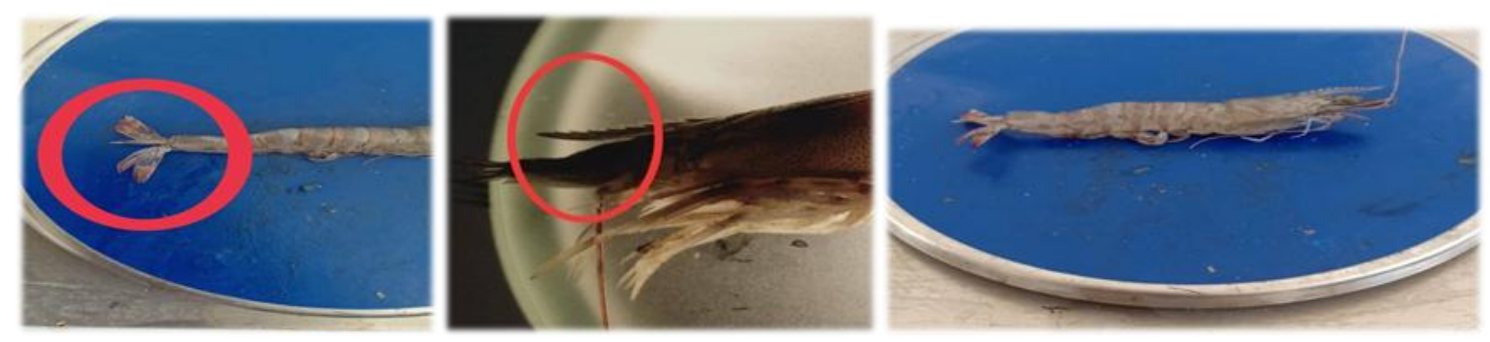

Fig. 5. Metapenaeus monoceros from Bardawil lagoon during fishing season, 2019
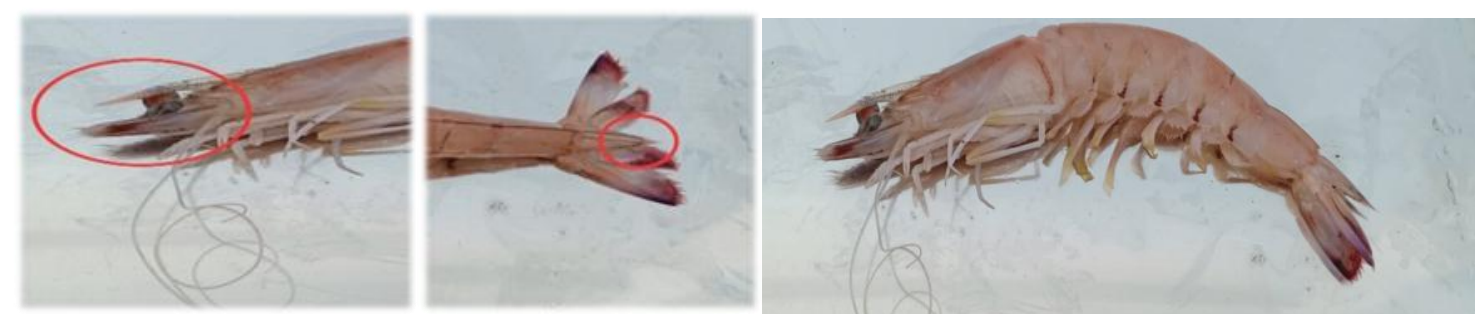

Fig. 6. Metapenaeus stebbingi from Bardawil lagoon during fishing season, 2019

\section{Conclusion}

During the present study, Randomly collection of samples and transported for taxonomic examinations and measurements. The present study was mainly based on the phenotype and meristic character observation of fresh specimens. and through the examination presence was recorded five species Penaeus semisulcatus, Metapenaeus stebbingi, Penaeus japonicus, Metapenaeus monoceros and Melicertus Keraturus in Bardawil lagoon in North Sinai and their identifying characters were very closely similar with the descriptions given by Many previous studies.

\section{REFERENCES}

Abusaif, S.M. (2017). Biological and fishery studies on The Commercial Prawn species (Marsupenaeus japonicus) on the western Mediterranean Egyptian coast. Marine Sci. Dept., Fac. Sci., Suez Canal Univ.

Bate, C.S. (1888). Report on the Crustacea Macrura collected by the Challenger during the years 1873-76. Report on the Scientific Results of the Voyage of H.M.S. Challenger During the Years
1873-76. Zool. 24 (part 52): i-xc, 1-942, 1-150.

Bowman, T.E. and Abele, L.G. (1982). Classification of recent Crustacea, In: L.G. Abele (Ed.). The Biology of the Crustacea. Systematics, the Fossil Record and Biogeography, Academic Press, New York, 1-27.

Brito, C. (2001). Towards an institutional theory of the dynamics of industrial networks, J. Business and Indust. Market., 16 (3): 150-166.

Charpenter, K.E. and Niem, V.H. (1998). FAO species identification guide for fishery purposes. The living marine resources of The Western Central Pacific Vol. 2. Cephalopods, Crustaceans, Holothurians and Sharks. FAO, Rome, 687-1396.

Crocos, P.J. (1987). Reproductive dynamics of the tiger prawn Penaeus esculentus, and a comparison with $P$. semisulcatus, in the north-western Gulf of Carpentaria, Australia. Marine and Freshwater Res., 38 (1): 91-102.

De Bruin, G.H.P.; Russell, B. and Bogusch, A. (1994). The Marine Fishery Resources of Sri Lanka, FAO species Identification guide for fishery purposes. FAO, Rome. 
De Haan, W. (1844). Crustacea. In: von Siebold, P.F., Fauna Japonica sive Descriptio Animalium, quae in Itinereper Japoniam, Jussu et Auspiciis Superiorum, qui Summum in India Batava Imperium Tenent, Suspecto, Annis 1823-1830 Collegit, Notis, Observationibus et Adumbrationibus Illustravit. $i$-xxxi, ixxvi, 1-243, Plates A-J, L-Q, 1-55. Lugduni-Batavorum.

Fabricius, J.C. (1798). Supplementum entomologiae systematicae. Proft et Storch, Hafniae [= Copenhagen], [2] + $572 \mathrm{pp}$.

FAO (2011). http://www.fao/org/fishery/ species/fact sheets/Melicertus kerathurus.

Forskål, P. (1775). Descriptions animalium avium, amphibiorum, piscium, insectorum, vermium; quæ in itinere orientali observavit Petrus Forskål. Post mortem auctoris edidit Carsten Niebuhr. Adjuncta est materia medica Kahirina atque tabula maris rubri geographica. pp. 1-20, [=1-34], 1-164, 1 map. Hauniæ (Möller).

GAFRD (2009). The general authority for fishery resources development: summary production statistics. Cairo, Egypt.

Guerra-Garcia, J.M.; Espinosa, F. and Garcia-Gómez, J.C. (2008). Trends in Taxonomy today: an overview about the main topics in Taxonomy. Zool. Baetica, 19:15-49.

Jayawickrama, S.J.C. (2010). Towards sustainable utilization of Penaeid prawn resources in Sri Lankan waters. Vidura, 13: 17-19.

Keat-Chuan, N.C.; Aun-Chuan, O.P.; Wong, W.L. and Khoo, G. (2017). A Review of Fish Taxonomy Conventions and Species Identification Techniques. J. Survey in Fisheries Sci., 4 (1): 54-93.

King, B.H. and King, R.B. (1995). Sibmating and its fitness consequences in the parasitoid wasp Spalangia cameroni (Hymenoptera: Pteromalidae). J. Insect. Behavior, 8: 723-730.
Salem, M. and El-Aiatt, A. (2012). Improvement of Trammel Net Landing and Reduction of fishing for Gilthead Sea bream (Sparus aurata) Juveniles in Bardawil lagoon, North Sinai, Egypt. J. Animal, Poultry and Fish Prod., Suez Canal Univ., Morphometric Analyses. J. Anim. Vet. Adv., 5 (3): 172-175.

NCMR (2002). Comparative studies of the state of population of Penaeus kerathurus shrimp in north Mediterranean. In: A.J. CONIDES and F.LUMARE (eds.), Final report, Research Project No. 0037/98 DG-XIV Fisheries: 238.

Nuri BAȘUSTA. (1997). Some Biological Aspects of Penaeid Shrimp Inhabiting Yumurtalık Bight in İskenderun Bay (North-Eastern Mediterranean) Meting KUMLU, Dursun AVŞAR, Tufan EROLDOĞAN Fac. Fisheries, Çukurova Univ., 01330 Balcalı, Adana-TURKEY.

Otero, M.; Cebrian, E.; Francour, P.; Galil, B. and Savini, D. (2013). Monitoring Marine Invasive Species in Mediterranean Marine Protected Areas (MPAs): A strategy and practical gui Malaga, Spain: IUCN, 136.

Piratheepa, S.; Chitravadivelu, K. and Edrisinghe, U. (2016). Taxonomic study and Identification key to the Species of the shrimps, particularly the Family Penaeidae in Kakkaithivu coastal waters, Jaffna, Sri Lanka. Int. J. Sci. and Res. Public., $6: 5$.

Rahnama, R.; Hosseini, S.J.; Qasemi, S.A.; Yavari, V.; Zolgharnein, H. and Matinfar, A. (2010). Preiminary molecular comparison of $P$. penaeus semisulcatus of Persion Gulf and its subspecies Penaeus semisulcatus persicus using 16S rRNA Modern Genetics, 25: 23-31.

Yassien, M.H. (2004). Biology and fishery of the green tiger prawn Penaeus semisulcatus De Haan (1850) in Bardawil Lagoon, Northern Sinai, Egypt. Bulletin of National Inst. Oceanography and Fisheries, ARE, 30:1-22. 


\section{الملخص العربي \\ دراسة تصنيفية للتعرف على أنواع الجمبري في منخفض البردئ

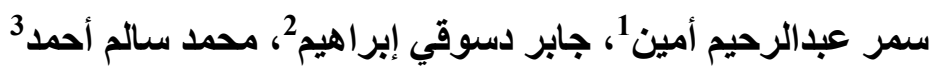

1- طالب دراسات عليا، قسم الثروة السمكية والأحياء المائية، كلية العلوم الزر اعية البيئية العريش، جامعة العريش، مصر.

2- قسم الثروة السمكية والأحياء المائية، كلية العلوم الزر اعية البيئية العريش، جامعة العريش، مصر.

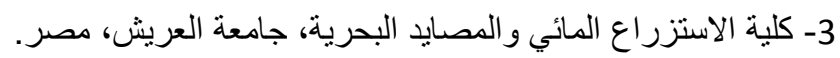

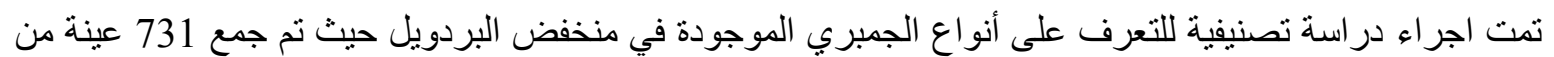

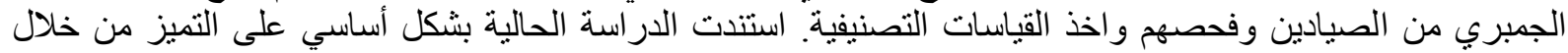

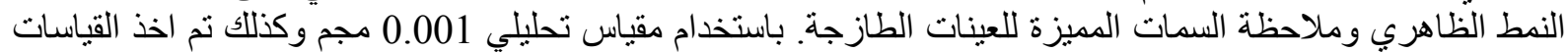

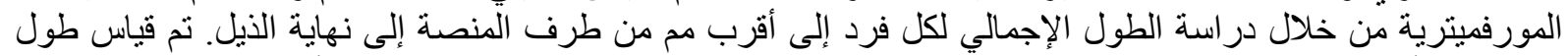

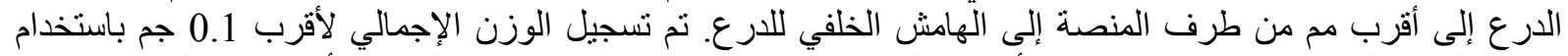

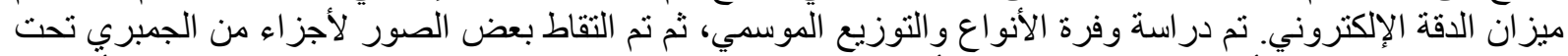

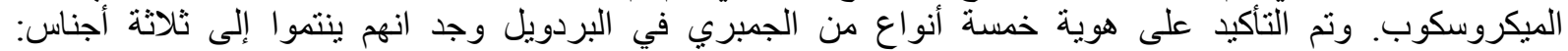

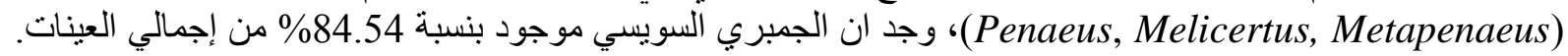

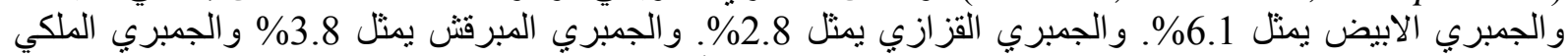

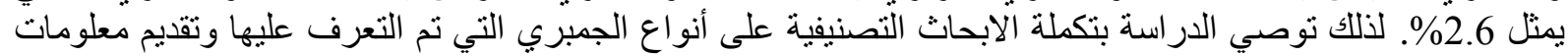

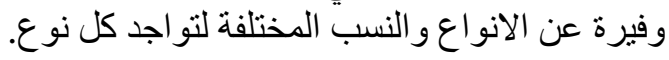

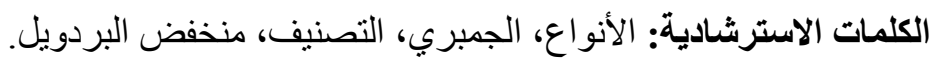

أستاذ بيولوجيا الأسماك و المصايد، كلية الزر اعة، جامعة قناة السويس، مصر. أستاذ بيولوجيا الأسماك المساعد، المعهد القومي لعلوم المحيطات والمعات ومصايد الأسماك، مصر.

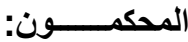

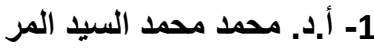

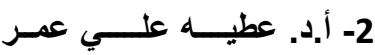


